\title{
Summer Thermal Comfort in Russian Big Cities (1966-2015)
}

\author{
Pavel Konstantinov ${ }^{A^{*}}$, Diana Tattimbetova ${ }^{A}$, Mikhail Varentsov $^{A}$, Natalia Shartova $^{\mathrm{A}}$ \\ Received: November 19, 2020 | Revised: March 21, 2021 | Accepted: March 22, 2021 \\ doi: 10.5937/gp25-29440
}

\begin{abstract}
The main goal of the study is the assessment of modern bioclimatic conditions (1966-2015) for determining the level of comfort in large Russian cities based on the observations at the meteorological stations, including Physiological Equivalent Temperature (PET) for the main extent of thermal comfort. According to the distribution of thermal stress events (calculated for meteorological fix hours, 8 times per day) the authors created the comfort diagram for each city during daytime heat wave period and evaluated their comfort conditions. In the current research we are operating with WMO climatic data for eleven biggest cities of the Russian Federation: from the European part (Moscow, Saint-Petersburg, Ekaterinburg, Voronezh, Volgograd, Kazan, Nizhny Novgorod, Perm, Ufa) and from Siberia (Omsk and Krasnoyarsk). The most interesting result of the comparison of the long-period (50 years) urban trends (PET-index and Air Temperature) in different parts of Russia is its extraordinary cross-shaped form in Moscow (in other cities the trends lines are practically parallel to each other). It means that at the level of the average annual values, only in Moscow the PET index (and, hence, potentially the thermal stress) grows faster than the regional climate warms. In other cities this tendency is much weaker (N.Novgorod) or not significant. This interesting tendency is caused by both Moscow related urban planning dynamics in post-USSR period and by regional climate dynamics.
\end{abstract}

Keywords: Physiological Equivalent Temperature (PET); regional urban climate; urban thermal comfort

\section{Introduction}

In recent times, the urban climate studies have inevitably shifted the emphasis towards the problems of sustainable development of (mega)cities. Such concept is closely connected with the studies of the human comfort in large cities in Europe and Asia. It is a rational approach to the resettlement and peaceful coexistence of a large number of people within the confines of a small territory (villages, cities, metropolises, etc.). From this point of view, the cities of the Russian Federation are an ideal monitoring platform, since the concept process of their development has just started. At the same time, it should be taken into account that the Russian Federation is a highly urbanized coun- try (Kolosov \& Nefedova, 2014), and this process has been connected to internal migration of the population since the 1970s.

Rapid urbanization in Russian Federation led to cities growth and its economic advance. Alongside this population of big cities (>1 000000 inhabitants) is quite vulnerable to heat wave events due to intensive urban heat island event (Kislov \& Konstantinov, 2011). In July and August 2010 in the biggest city in Russia - Moscow, where more than 11 million people live, the longest and the strongest heat wave as well as the warmest day (29th of July 2010) were recorded since the meteorological observations in Russia (Konstan-

\footnotetext{
A Lomonosov Moscow State University, Faculty of Geography, Leninskie Gory 1119991 ; kostadini@mail.ru; diano4ka_07.07.95@mail.ru, mvar91@gmail.com, shartova@yandex.ru

* Corresponding author: Pavel Konstantinov; e-mail: kostadini@mail.ru
} 
tinov et al., 2014). There were close to 11000 excess deaths from non-accidental causes (predominantly temperature and air pollution) during this period, mainly among people older than 65 years. Increased risks (Zemtsov et al., 2020) also occurred in younger age groups (Shaposhnikov et al., 2014). Thus, the main goal of the study is the assessment of modern bioclimatic conditions (1966-2015) for determining the level of comfort in large Russian cities based on the observations at meteorological stations.

Also, the variety of natural and climatic conditions in the Russian Federation allows to study the bioclimatic characteristics of the large cities (there are 15 cities with more than 1 million inhabitants in Russia) in various subtypes of the temperate zone (from marine to ultracontinental). The similar conditions of planning efforts in these big cities create a uniform background of administrative influence on the part of the government. This allows to identify in which geographical regions the traditional type of city management is more successful from a bioclimatic point of view. In other words, in which regions conditions of thermal comfort in cities is a successor of air temperature trends and in which not.

Of course, within the framework of this study, we accept the hypothesis that changes in the trends of thermal comfort in Russian cities are associated with both the change in the regional climate and with the change of land-use properties in the urban environment. However, since the natural factor acts with approximately the same strength, noticeable differences in trends (if they are detected) can be generated by the influence of the urban microclimate, which is indirectly related to urban development strategies.

\section{Materials and Methods}

This study is based on the characterization of the climatic trends of human thermal comfort and its assessment during heat wave periods. From the standpoint of human health heat wave is a period of time in which an excessive stress of thermoregulation of the body is accessed, as well as an increased risk of morbidity and mortality, especially from respiratory and cardiovascular diseases (Robinson, 2001; Arsenović et al., 2019; Urban et al 2019).

There are many approaches to the definition of heat waves. For this study the most convenient criteria developed by the World Meteorological Organization (WMO) was chosen. According to it, the heat wave is the excess of the maximum temperature for five consecutive days or more at $5^{\circ} \mathrm{C}$ from the average maximum value for the base period from 1961 to 1990 (Frich et al., 2002)

In this study we choose Physiological Equivalent Temperature (PET) for the main extent of thermal comfort. "Equivalent-physiological temperature for a given place" is the air temperature at which for ordinary room conditions the heat balance of the human body remains unchanged with the internal body temperature and skin temperature for a given situation (Hoppe, 1999) This, however, does not mean that this index can not be applied to the open spaces. On the contrary, it helps a person to compare sensations he/she has in the open air with the room conditions that are familiar to him - some evaluations for Russian Federation were described in paper (Shartova et al., 2018).

The basis for the study was the analysis of standartized data from the regular Roshydromet (Russian WMO meteorological network) over a 50 -year period from 1966 to 2015 . This was due to the fact that the best quality data of instrumental observations were available during this period. Russia's cities with population of 1 million were chosen as the objects of the research.

In current research we are operating with WMO climatic data for 11 biggest cities of the Russian Federation: from the European part (Moscow, Saint-Petersburg, Ekaterinburg, Voronezh, Volgograd, Kazan, Nizhny Novgorod, Perm, Ufa) and from Siberia (Omsk and Krasnoyarsk). A brief description of each city is given in Table 1.

For calculating PET index we used RayMan model which is widely used in the European practice. For example, with the help of this model the PET index was calculated in Freiburg, Germany, or, more precisely, in the center of this city. The frequency of observed certain gradations of the comfort level by the PET index was calculated with Rayman, as well as the local maps of the bioclimatic comfort of this area (Frohlich \& Matzarakis, 2010). The same index was applied in 2010 for the detailed analysis of the bioclimatic conditions of Freiburg for the conditions of the modern climate (period 1961-1990) and the forecast period (20712100) based on IPCC scenarios (Matzarakis \& Endler, 2010). In general, the results show that the number of days with heat stress conditions has increased.

Another example of using this index with RayMan is the study based on the data analysis of 33,212 hospitalizations among people over 60 years old in São Paulo, Brazil between 2003 and 2007. (Silva \& Ribeiro, 2012). The results of the study showed the increase in the probability of hospitalization among the group of people in unsatisfactory socio-economic conditions 
Table 1. Main big cities of Russian Federation: geographical overview (Bolshaya..., 2007; Census, 2010)

\begin{tabular}{|c|c|c|c|c|c|}
\hline City & Population & Coordinates & $\begin{array}{l}\text { WMO station } \\
\text { ID }\end{array}$ & $\begin{array}{c}\text { Köppen } \\
\text { climate zone }\end{array}$ & Basic climatic info \\
\hline Moscow & 11503501 & $\begin{array}{l}55^{\circ} 45^{\prime} \mathrm{N} \\
37^{\circ} 37^{\prime} \mathrm{E}\end{array}$ & 27612 & Dfb & $\begin{array}{l}\text { Coldest month: January }\left(-9.4^{\circ} \mathrm{C}\right) \\
\text { Warmest month: July }\left(+18.3^{\circ} \mathrm{C}\right) \\
\text { Average annual rainfall: } 684 \mathrm{~mm}\end{array}$ \\
\hline Saint-Petersburg & 4879566 & $\begin{array}{l}59^{\circ} 57^{\prime} \mathrm{N} \\
30^{\circ} 18^{\prime} \mathrm{E}\end{array}$ & 26063 & Dfb & $\begin{array}{l}\text { Coldest month: January }\left(-5^{\circ} \mathrm{C}\right) \\
\text { Warmest month : July }\left(+18^{\circ} \mathrm{C}\right) \\
\text { Average annual rainfall: } 661 \mathrm{~mm}\end{array}$ \\
\hline Ekaterinburg & 1349772 & $\begin{array}{l}56^{\circ} 50^{\prime} \mathrm{N} \\
60^{\circ} 35^{\prime} \mathrm{E}\end{array}$ & 28440 & Dfb & $\begin{array}{l}\text { Coldest month: January }\left(-12.6^{\circ} \mathrm{C}\right) \\
\text { Warmest month: July }\left(+19^{\circ} \mathrm{C}\right) \\
\text { Average annual rainfall: } 537 \mathrm{~mm}\end{array}$ \\
\hline Voronezh & 889680 & $\begin{array}{l}51^{\circ} 40^{\prime} \mathrm{N} \\
39^{\circ} 12^{\prime} \mathrm{E}\end{array}$ & 34123 & Dfb & $\begin{array}{l}\text { Coldest month: January }\left(-6.1^{\circ} \mathrm{C}\right) \\
\text { Warmest month: July }\left(+20^{\circ} \mathrm{C}\right) \\
\text { Average annual rainfall: } 587 \mathrm{~mm}\end{array}$ \\
\hline Volgograd & 1021215 & $\begin{array}{l}48^{\circ} 42^{\prime} \mathrm{N} \\
44^{\circ} 31^{\prime} \mathrm{E}\end{array}$ & 34560 & Dfa & $\begin{array}{l}\text { Coldest month: January }\left(-6.3^{\circ} \mathrm{C}\right) \\
\text { Warmest month: July }\left(+23.6^{\circ} \mathrm{C}\right) \\
\text { Average annual rainfall: } 347 \mathrm{~mm}\end{array}$ \\
\hline Kazan & 1141535 & $\begin{array}{c}55^{\circ} 47^{\prime} \mathrm{N} \\
49^{\circ} 06^{\prime} 3 \mathrm{E}\end{array}$ & 27595 & Dfb & $\begin{array}{l}\text { Coldest month: January }\left(-10.4^{\circ} \mathrm{C}\right) \\
\text { Warmest month : July }\left(+20.2^{\circ} \mathrm{C}\right) \\
\text { Average annual rainfall: } 558 \mathrm{~mm}\end{array}$ \\
\hline Krasnoyarsk & 973826 & $\begin{array}{l}56^{\circ} 01^{\prime} \mathrm{N} \\
93^{\circ} 04^{\prime} \mathrm{E}\end{array}$ & 29572 & DfC & $\begin{array}{l}\text { Coldest month: January }\left(-15.5^{\circ} \mathrm{C}\right) \\
\text { Warmest month : July }\left(+15.7^{\circ} \mathrm{C}\right) \\
\text { Average annual rainfall: } 465 \mathrm{~mm}\end{array}$ \\
\hline Nizhny Novgorod & 1250619 & $\begin{array}{l}56^{\circ} 19^{\prime} \mathrm{N} \\
44^{\circ} 00^{\prime} \mathrm{E}\end{array}$ & 27459 & Dfb & $\begin{array}{l}\text { Coldest month: January }\left(-12^{\circ} \mathrm{C}\right) \\
\text { Warmest month: July }\left(+18.1^{\circ} \mathrm{C}\right) \\
\text { Average annual rainfall: } 648 \mathrm{~mm}\end{array}$ \\
\hline Omsk & 1154116 & $\begin{array}{l}54^{\circ} 59^{\prime} \mathrm{N} \\
73^{\circ} 22^{\prime} \mathrm{E}\end{array}$ & 28698 & Dfb & $\begin{array}{l}\text { Coldest month: January }\left(-16.3^{\circ} \mathrm{C}\right) \\
\text { Warmest month : July }\left(+19.6^{\circ} \mathrm{C}\right) \\
\text { Average annual rainfall: } 415 \mathrm{~mm}\end{array}$ \\
\hline Perm & 991162 & $\begin{array}{l}58^{\circ} 00^{\prime} \mathrm{N} \\
56^{\circ} 19^{\prime} \mathrm{E}\end{array}$ & 28224 & Dfc & $\begin{array}{l}\text { Coldest month: January }\left(-12.6^{\circ} \mathrm{C}\right) \\
\text { Warmest month : July }\left(+18.6^{\circ} \mathrm{C}\right) \\
\text { Average annual rainfall: } 638 \mathrm{~mm}\end{array}$ \\
\hline Ufa & 1062319 & $\begin{array}{l}54^{\circ} 44^{\prime} \mathrm{N} \\
56^{\circ} 00^{\prime} \mathrm{E}\end{array}$ & 28722 & Dfb & $\begin{array}{l}\text { Coldest month: January }\left(-12.4^{\circ} \mathrm{C}\right) \\
\text { Warmest month : July }\left(+19.76^{\circ} \mathrm{C}\right) \\
\text { Average annual rainfall: } 590 \mathrm{~mm}\end{array}$ \\
\hline
\end{tabular}

by $12 \%$ with the increase in the value of the bioclimatic index by $10^{\circ} \mathrm{C}$.

In this study, we use the Rayman model on a onedimensional scale, without taking into account environmental obstacles and SVF in WMO-station standard environment.

Since there is no other long-term data for a similar period on the territory of the studied cities, it is as- sumed in the study that the measurement data characterize the city climate quite reliably. According to LCZ climate zones classification (Stewart \& Oke, 2012), WMO station areas in cities, selected for longterm trend investigation (Moscow, Saint-Petersburg, Nizhny Novgorod, Perm, Ekaterinburg and Krasnoyarsk) are situated in Type 6 (Open low-rise) and Type 9 (Sparsely built)- see Fig.1 

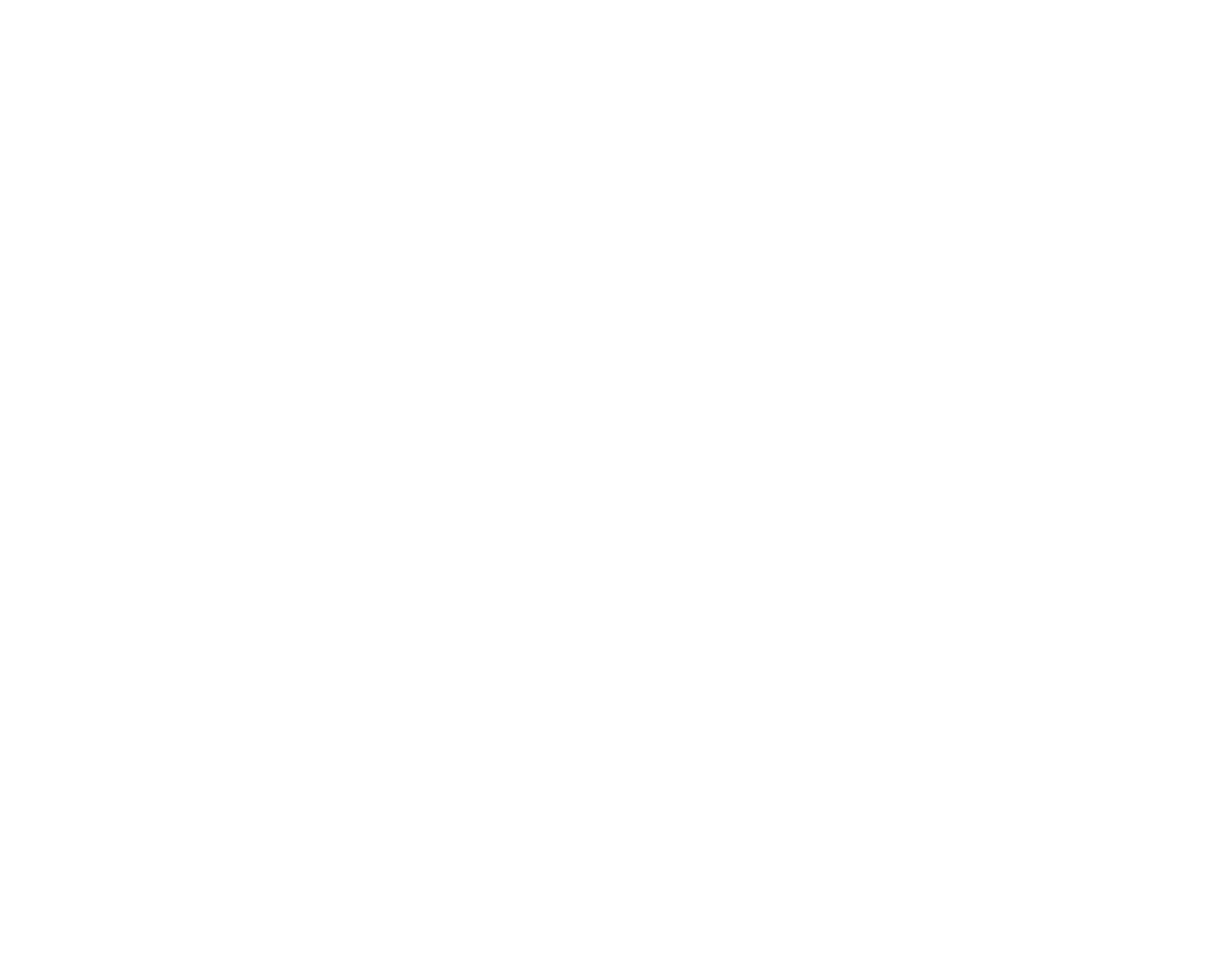

Figure 1. Satellite images of the cities, considered in the study (taken from Google maps) with locations of the used weather stations indicated by asterisk symbols (right panels). Right panees shows satellite images of the nearest surrounding of the weather stations (area within yellows squares in the left panels)

\section{Results}

According to the distribution of thermal stress events it is possible to create comfort diagram for each city during daytime heat wave period (for Moscow and Saint-Petersburg see Fig.2).

This plot shows that in both capitals the greatest frequency during daytime is in strong heat stress area (33.3\% and 39.6\%). Frequency of extreme heat stress in
Moscow is $13.8 \%$ and in Saint-Petersburg 5.3\%. The cases of comfortable sensations in the period of heat waves for the whole warm period in Moscow constitute only 6.9\%. The lowest frequency is graded as "a slightly cold stress" which corresponds to a slight cold exposure (0.2\%).

In general, we can say that in Moscow during the period of heat waves people in $47.5 \%$ of cases is vul-
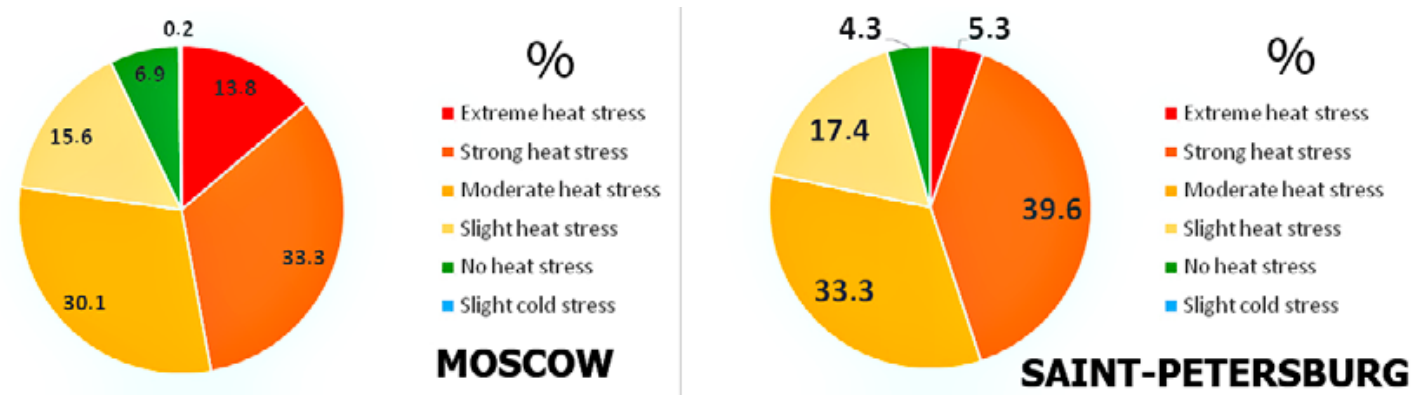

Figure 2. Frequency of PET grades in Moscow and Saint-Petersburg in the day time during heat waves (1966 - 2015 period) 
Table 2. Mean-Decade Trends for Air Temperature and for PET in different parts of Russian Federation in 1966-2015

\begin{tabular}{|l|c|c|c|c|c|c|}
\hline $\begin{array}{l}\text { Cities, Russian } \\
\text { Federation }\end{array}$ & Moscow & $\begin{array}{c}\text { Saint- } \\
\text { Petersburg }\end{array}$ & $\begin{array}{c}\text { Nizhny } \\
\text { Novgorod }\end{array}$ & Perm & Ekaterinburg & Krasnoyarsk \\
\hline $\begin{array}{l}\text { Air temperature } \\
\text { linear trend }\end{array}$ & $0.36^{\circ} \mathrm{C} / 10 \mathrm{yr}$ & $0.40^{\circ} \mathrm{C} / 10 \mathrm{yr}$ & $0.38^{\circ} \mathrm{C} / 10 \mathrm{yr}$ & $0.34^{\circ} \mathrm{C} / 10 \mathrm{yr}$ & $0.36^{\circ} \mathrm{C} / 10 \mathrm{yr}$ & $0.29^{\circ} \mathrm{C} / 10 \mathrm{yr}$ \\
\hline PET linear trend & $0.93^{\circ} \mathrm{C} / 10 \mathrm{yr}$ & $0.25^{\circ} \mathrm{C} / 10 \mathrm{yr}$ & $0.83^{\circ} \mathrm{C} / 10 \mathrm{yr}$ & $0.47^{\circ} \mathrm{C} / 10 \mathrm{yr}$ & $0.54^{\circ} \mathrm{C} / 10 \mathrm{yr}$ & $0.24^{\circ} \mathrm{C} / 10 \mathrm{yr}$ \\
\hline
\end{tabular}

nerable to heat stress. In Saint-Petersburg this value is $44.9 \%$

Based on the results obtained in the process of the PET index calculation we plotted a map-diagram which shows the distribution of various degrees of heat stress in 11 large cities of Russia. (Fig.3)

Proceeding from this, we can conclude that the most inclined to heat stress city in the heat waves in the daytime is Volgograd, as Volgograd is one of the hottest cities in Russia. Main PET and air temperature trend results can be briefly summarized in Table 2 .

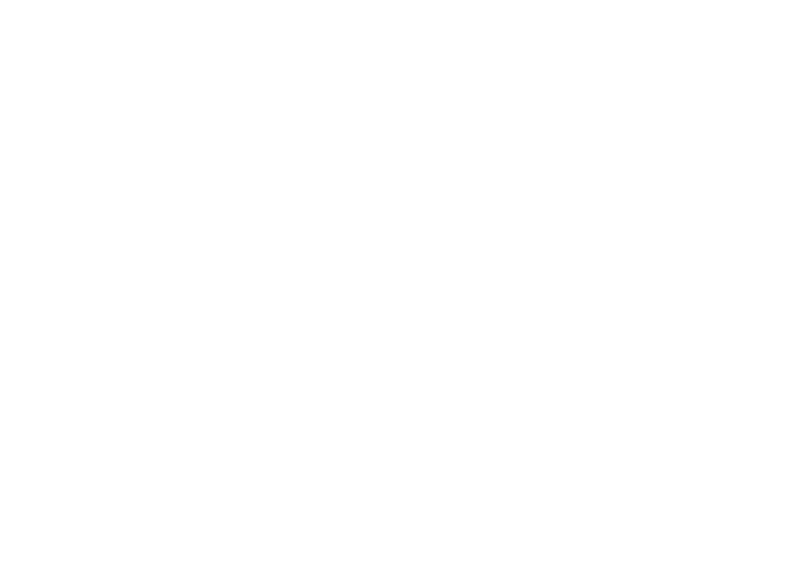

Figure 3. Level of thermal stress in big Russian cities in the day time during heat waves (1966 - 2015 period)

\section{Discussion}

So, what if we decide to take a look at long period trends of PET and air temperature in cities of different parts of Russia? We know that climate is changing, air temperature rises in most parts of the Russia (Federal Service for Hydrometeorology and Environmental Monitoring, Roshydromet, 2014). But the thermal comfort is complex characteristic and its trend can clarify the real tendencies of human comfort sensation against the background of regional climate change (see Fig.4)

It is well known that the cities' growth leads to the increase in trends of warming of the local urban climate, which is due to the joint impact of the global climate trends and the impact of the urban heat island (Kataoka et al., 2009). However, practically noth-

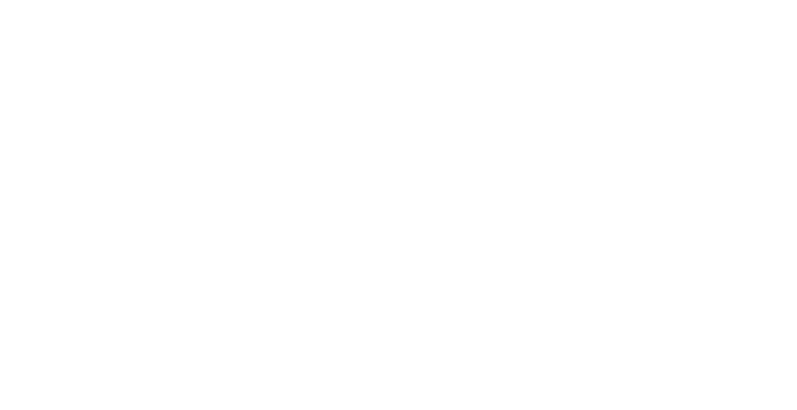

Figure 4. Linear trends of PET-index (annual mean for warm period) and air temperature (annual mean for warm period) in different parts of Russian Federation in 1966-2015 ing is known about the relationship between temperature growth and changes in comfort parameters on the territory of Russia.

The most interesting result of the comparison of the urban trends (PET-index and Air Temperature) in different parts of Russia is its extraordinary cross-shaped form in Moscow (in other cities the trends lines are practically parallel to each other): in further research we plan to investigate such phenomenon by using different thermal comfort indices (UTCI etc) It can be caused just as by Moscow related urban planning dynamics in post-USSR period so by regional climate dynamics. The more detailed analysis of the dynamics of PET-predictors (direct solar radiation, wind speed), indicates that its growth is due to the presence of significant negative trends for wind speed and a score of lower clouds. The obvious, at first glance, the explanation of such well-pronounced wind speed trends - an increase in the roughness in the vicinity of the stations against the background of local land use change. However, the obtained trends for the Moscow region are in good agreement with the estimates from (Federal Service for Hydrometeorology and Environmental Monitoring, Roshydromet, 2014) and (Meshcherskaya, 2004; 2006), according to which the decrease in wind speed with speeds of $0.1-0.5 \mathrm{~m} / \mathrm{s} / 10$ years over the last decades is typical for the European territory of Russia.

The trend of the decrease in the lower cloudiness in Moscow is making the greatest contribution to the 
relative discomfort in summer is manifested more evidently. The similar changes are consistent with the trend of increasing duration sunshine against the background of the increase in the total cloud score for Moscow and Kazan (Gorbarenko et al., 2017; Sidorenko et al., 2012) and the trend of erythema ultraviolet radiation (Chubarova et al., 2018).

We used a small number of cities in our research and can not say about the global trends in the country, nevertheless it is possible to make some valuable conclusions.

The high probability of the heat stress is more evident for large and fast-evolving cities of Central Russia. The faster growth of PET temperatures is observed as compared to air temperatures. This is confirmed by the examples of Moscow and Nizhny Novgorod (PETwarming trend is two times more intensive than thermal one). We can suggest that the cross-shaped form of $\mathrm{T}$ and PET can be noticed in Nizhny Novgorod soon.

The maritime climate of Saint Petersburg (the only city with this type of climate among the observed) has the impact on the conditions of thermal comfort. Despite the increase of $\mathrm{T}$ the significant changes in PET (feeling of heat for human) did not occur. The probability of heat stress in this city is inconsiderable.
Perm and Yekaterinburg are both located in the area of the Ural Mountains and have similar trends in PET values. We can observe the increase in PET greatly correlated with temperature changes without any unusual effects.

Krasnoyarsk has the most continental climate type among the cities reviewed. We can observe small difference between $\mathrm{T}$ and PET in addition to the growth of both parameters. Krasnoyarsk can be considered as the city with the lowest probability of heat stress.

An argumentative issue, of course, is the choice of this particular parameter (the frequencies of PET grades) for determining the relative risk of thermal discomfort phenomenon. However, taking into account the absolute temperature values of thermal waves is also not ideal - because of both the adaptation of the population of more southern regions to hot weather, and the vulnerability of the criterion (Frich et al., 2002) for determining heat waves in the northern regions.

The obtained results can be considered in the further analysis with larger number of weather stations and can used for categorization of cities according to the level and the dynamics of thermal comfort conditions.

\section{Conclusions}

Within the frames of this study, the PET equivalent-physiological temperature index was calculated for each day of the warm period for 11 biggest cities of Russia. Based on the results of the calculations, we have plotted the diagrams with the frequency of occurrence of extreme thermal events during the heat waves for each town.

Also showed that at the level of the average annual values, only in Moscow-city the PET index (and, hence, potentially the thermal stress) grows faster than the regional climate warms $\left(0.93^{\circ} \mathrm{C} / 10 \mathrm{yr}\right.$ for PET and $0.36^{\circ} \mathrm{C} / 10 \mathrm{yr}$ for air temperature). In other cities this tendency is much more weak (N.Novgorod) or not significant. The most inclined to risk city during the heat waves in the daytime is Volgograd, while St. Petersburg can be considered the safest, since the frequency of thermal stress even in this dangerous period does not exceed $5.3 \%$ of all the cases.

The main result achieved during the study is the creation of Russia's first comparative climatology of comfort in biggest cities and the determination of the relative danger of heat waves for each of them based on the analysis of 50 year time series, as well as the determination of the dynamics of heat comfort indices for the last 50 years (1966-2015).

\section{Acknowledgments}

Research was supported by the grant program of Russian Science Foundation (project no. 17-77-20070 "An initial assessment and projection of the bioclimatic comfort in Russian cities in XXI century against the context of climate change").

\section{Author Contributions}

Pavel Konstantinov and Natalia Shartova conceived and designed the experiments; Diana Tattimbetova performed the experiments with Rayman model for warm season periods; Pavel Konstantinov and Mikhail Varentsov analyzed the data; Pavel Konstantinov finally wrote the paper. 


\section{References}

Arsenović, D., Lehnert, M., Fiedor, D., Šimáček, P., Středová, H., Středa, T., \& Savić, S. (2019). Heatwaves and mortality in Czech cities: A case study for the summers of 2015 and 2016. Geographica Pannonica, 23(3), 162-172.

Osipov, Y. (Ed.) (2007). Bol'shaya Rossiyskaya entsiklopediya [The Great Russian Encyclopedia]. Vol. 5. Moscow: Bol'shaya Rossiyskaya entsiklopediya: 710-783 (in Russian).

Frich, P., Alexander, L. V., Della-Marta, P. M., Gleason, B., Haylock, M., Tank, A. K., \& Peterson, T. (2002). Observed coherent changes in climatic extremes during the second half of the twentieth century. Climate research, 19(3), 193-212.

Fröhlich, D., \& Matzarakis, A. (2013). Modeling of changes in thermal bioclimate: examples based on urban spaces in Freiburg, Germany. Theoretical and Applied Climatology, 111(3), 547-558.

Kislov, A. V., \& Konstantinov, P. I. (2011). Detailed spatial modeling of temperature in Moscow. Russian Meteorology and Hydrology, 36(5), 300-306. https://doi.org/10.3103/S1068373911050037

Kolosov, V.A. \& Nefedova, T.G. Reg. Res. Russ. (2014) 4: 68. https://doi.org/10.1134/S2079970514020099

Konstantinov, P. I., Varentsov, M. I., \& Malinina, E. P. (2014). Modeling of thermal comfort conditions inside the urban boundary layer during Moscow's 2010 summer heat wave (case-study). Urban Climate, 10, 563-572.

Höppe, P. (1999). The physiological equivalent temperature-a universal index for the biometeorological assessment of the thermal environment. International journal of Biometeorology, 43(2), 71-75.

Johansson, E. (2006). Influence of urban geometry on outdoor thermal comfort in a hot dry climate: A study in Fez, Morocco. Building and environment, 41(10), 1326-1338.

Kataoka, K., Matsumoto, F., Ichinose, T., \& Taniguchi, M. (2009). Urban warming trends in several large Asian cities over the last 100 years. Science of the total environment, 407(9), 3112-3119.

Matzarakis, A., \& Endler, C. (2010). Climate change and thermal bioclimate in cities: impacts and options for adaptation in Freiburg, Germany. International journal of biometeorology, 54(4), 479-483.

Mescherskaya, A. V., Getman, I. F., Borisenko, M. M., \& Shevkunova, E. I. (2004). Monitoring of windspeed in the Volga River catchment and the Ural region in the twentieth century. Russian Meteorology and Hydrology, 3, 83-97.
Mescherskaya, A. V., Eremin, V. V., Baranova, A. A., \& Maystrova, V. V. (2006). Change in wind speed in northern Russia in the second half of the twentieth century, from surface and upper air data. Russian Meteorology and Hydrology, 9, 46-58..

Silva, E. N. D., \& Ribeiro, H. (2012). Impact of urban atmospheric environment on hospital admissions in the elderly. Revista de Saúde Pública, 46(4), 694-701.

Robinson, P. J. (2001). On the definition of a heat wave. Journal of Applied Meteorology and Climatology, 40(4), 762-775.

Shaposhnikov D, Revich B, Bellander T, et al. Mortality Related to Air Pollution with the Shaposhnikov, D., Revich, B., Bellander, T., Bedada, G. B., Bottai, M., Kharkova, T., Kvasha, E., Lezina, E., Lind, T., Semutnikova, E. \& Pershagen, G. (2014). Mortality related to air pollution with the Moscow heat wave and wildfire of 2010. Epidemiology (Cambridge, Mass.), 25(3), 359-364. doi:10.1097/ EDE.0000000000000090

Shartova, N., Shaposhnikov, D., Konstantinov, P., \& Revich, B. (2018). Cardiovascular mortality during heat waves in temperate climate: an association with bioclimatic indices. International Journal of Environmental Health Research, 28(5), 522-534. https://doi.org/10.1080/09603123.2018.1495322

Stewart, I. D. (2011). A systematic review and scientific critique of methodology in modern urban heat island literature. International Journal of Climatology, 31(2), 200-217. doi:10.1002/joc.2141

Stewart, I. D., \& Oke, T. R. (2012). Local climate zones for urban temperature studies. Bulletin of the American Meteorological Society, 93(12), 1879-1900. doi:10.1175/BAMS-D-11-00019.1

Federal Service for Hydrometeorology and Environmental Monitoring (Roshydromet). 2014. The Second Roshydromet Assessment Report on Climate Change and its Consequences in the Russian Federation. General Summary. Moscow: Roshydromet.

Urban, A., Hondula, D. M., Hanzlíková, H., \& Kyselý, J. (2019). The predictability of heat-related mortality in Prague, Czech Republic, during summer 2015A comparison of selected thermal indices. International journal of biometeorology, 63(4), 535-548.

Zemtsov, S., Shartova, N., Varentsov, M., Konstantinov, P., Kidyaeva, V., Shchur, A., Timonin, S. \& Grischchenko, M. (2020). Intraurban social risk and mortality patterns during extreme heat events: A case study of Moscow, 2010-2017. Health \& Place, 66, 102429. https://doi.org/10.1016/j.healthplace.2020.102429 